\title{
Coordination and integration in health care. The concepts for the next reform - part I
}

\author{
Przemysław Szetela
}

Katedra Zdrowia Publicznego, Dietetyki i Chorób Cywilizacyjnych, Wydział Medyczny, Wyższa Szkoła Informatyki i Zarządzania, Rzeszów

Address for correspondence: Przemysław Szetela, Katedra Zdrowia Publicznego, Dietetyki i Chorób Cywilizacyjnych, Wydział Medyczny, Wyższa Szkoła Informatyki i Zarządzania, ul. Sucharskiego 2, 35-225 Rzeszów, pszetela@wsiz. rzeszow.pl

\section{Abstract}

The concept of coordinated and related integrated health care is playing an increasingly important role in modern health care systems. Societies' changing health profile, particularly in developed countries, together with the growing complexity of the health care process necessitates searching for, and implementing, solutions to increase the effectiveness and efficiency of the existing systems. This is particularly necessary when there are no opportunities for a rapid and substantial increase in funding. The substance of the planned and implemented changes is the transition from episodic, fragmented, and dispersed treatment of diseases towards the provision of coordinated health care - with a varied degree of integration which would ensure that patients receive comprehensive and continuous treatment ensured by cooperation between the health care, social care and education sectors. Achieving solution to the above challenges is included in the concept of coordinated and integrated health care, some elements of which are being implemented in the Polish system of health care.

The purpose of this paper is to present the essential aspects of the philosophy of coordinated health care and the often related concept of integration in the health care system. The starting point for this consideration of the concept of coordinated health care is its origin and its development to date. The paper also focusses on the attempts made to implement the concept in the Polish health care system and on the currently formulated proposals concerning this matter.

\section{Key words: integration, comprehensiveness, coordination}

Stowa kluczowe: integracja, kompleksowość, koordynacja

\section{Introduction}

Coordination primarily means structured, or harmonised, interaction between different entities and issues, often autonomous and unrelated to health, which is important for achieving greater benefits or limiting the various costs and losses. The need for coordination is essential for efficiently governing and managing processes which are becoming ever more complex. The concept to health care coordination of is not new. The ancient Greeks were already aware of the complexity of medical problems. Asclepius, the god, doctor and coordinator had several auxiliary deities like Podalirius, Machaon, Telesphoros, Panacea, Hygieia, and Aceso and he coordinated their actions. The advancements in medical and health sciences have led to the need to specialise in particular medical professions. There are 23 medical professions in the Polish health care sector, including over 70 doctors' specialisations, 12 nurses' specialisations and 12 pharmaceutical specialisations. At the same time, the organisational structure of the institutions dealing with medical treatments has been considerably differentiated and it has become more complex, from the staff-line, through divisions, to the matrix. The relationship of individual contacts with individual patients has shifted to a transactional approach, replacing patient treatment with the implementation of particular procedures [1].

The concept of coordination is often used interchangeably with integration, thus, obscuring the substance of the problem. The concept of integration in health care 
includes the intentional process of combining, or merging, many and various elements of the system into a single entity. This combination covers many measures and perspectives which are used in health care [2]. Integration can refer to an individual perspective or can be directed towards a population or a selected group. It can cover local activities, but it can also reach regional or national levels. It may refer to the standard of treatment for a particular medical condition or a medical speciality. Integration, which in practice often means merging the actions of several subjects into one organism, or individual actions into a collective action, has increasingly become a necessity.

\section{The origin and evolution of the concept of coordinated healthcare}

The philosophy of coordinated health care was born in the United States of America in the 1930s, so the concept is almost 100 years old. The primary impetus for the emergence and development of coordinated health care in the United States originated from specific organisational and economic needs. It was primarily related to the policy for stimulating economic growth following the Great Depression of 1929-1933. A significant obstacle to overcoming the economic crisis was the low mobility of workers, who were reluctant to accept employment at construction projects located far from their place of residence. To overcome this reluctance, employers offered additional benefits, including medical care for their employees and their families. This initiative, the first of its type, was introduced by Henry Kaiser, a doctor and construction company owner after whom the largest coordinated health care organisation in the USA, the Kaiser Health Plan, is named. The principle of the scheme was a simple pre-paid policy in return for accepting responsibility for providing medical care for several thousand workers, and their families, employed on construction sites remote from health centres [3, 4]. This principle has led to a flagship organisational and legal form of the concept of coordinated healthcare in the United States, the HMO (Health Maintenance Organization). The significant increase in medical care costs observed in the 1970s in many countries, but primarily in the United States, the so-called "cost explosion" phenomenon, was a major stimulus for further development of the principle of coordinated care. Healthcare policymakers have sought organisational solutions that would introduce the missing elements of planning, coordination and control to the health system, which would increase the efficiency and reduce overall spending. The consequence is the development of coordinated healthcare [3].

In the $1980 \mathrm{~s}$, the poor quality of the healthcare system in many countries began to be linked, not only to underfinancing of the healthcare sector, but also to the inadequate management of the existing resources. Many opinions appeared criticising the division and fragmentation of care, the lack of continuity and co-operation by individual units and the inadequate levels of care to address specific problems [5]. The above assumptions are seen as the main reason for the further dynamic development of the philosophy of coordinated health care.

\section{The definition and essential elements of the concent of coordinated health care}

Coordinated health care is an ambiguous, non-homogeneous, concept and at the same time extremely "capacious". Attempts to define it precisely often cause many arguments. Terms such as "integrated care", "managed care", "continuous care", "comprehensive care", "care management" or "network healthcare" are very freely used in the subject literature. The term koordynowana opieka zdrowotna in Polish is the most frequently used Polish translation of the English term managed care or managed healthcare. Individual countries have adapted this terminology to their needs, and so Sweden uses the term managed care, the UK shared care, the Netherlands complex care, transmural zorg and Germany network care, vernetzung. All the above terms attempt to include both the purpose and the approach to health care.

Coordinated care is a concept that encompasses a number of different mechanisms and in practice it may vary widely. This concept does not mean a homogeneous form of health care, for there are frequent discussions about what can, or cannot, be called coordinated care [5]. In the subject literature, coordinated health care is more generally regarded as a certain philosophy, concept, or idea for the system. It is also understood to be specific solutions, which is the application of specific methods and techniques for organising and financing healthcare. It is also perceived as a method of managing, or directing, multiple entities to achieve a more general purpose which exceeds the goal of a single entity. This includes the planning of activities for the entire sector, increasing the coordinating role of the government and its agencies, creating the coordinating institution at the central level or regional levels and organizing the network, etc. Coordination should be understood primarily as a structured interaction between different entities and issues, which are often autonomous and unrelated to health, which is important for achieving more beneficial effects or limiting different costs or losses.

However, the concept of coordinated care is also frequently used for a specific although differentiated organisational form of health care provision, combining the characteristics of providers, usually the networks of doctors and medical centres, and the insurers. The existence of coordinated health care is commonly identified, but not always correctly, by the very fact of connecting the function of the insurer and the provider of health care services within one institution. However, this arrangement is much closer to being integrated care, rather than coordinated care. In today's concept of coordinated health care, the integration of the role of the buyer and supplier of broadly defined healthcare and individual health services occurs to a varying degree [6]. Integration can be regarded as one of the features of coordinated 
care that does not prejudge its existence. Coordination in healthcare is also often identified with a network of cooperating medical providers, created by managers who take over the financial and organisational responsibility and provide access to a relatively wide range of medical services and coordinate the care for their patients. This ensures comprehensive and continuity of treatment as well as the internal supervision of its quality, a network approach. In the network, the coordination mechanism is the contract [7]. Network coordination is sometimes called humanistic coordination because it reflects the human endeavour to cooperate and to establish social relationships $[7,8]$. The explanation for the establishment of such forms is the ability of the network to reduce transaction costs, usually through vertical integration. ${ }^{2}$

Coordinated health care (in Polish KOZ) is defined by the Polish Association of Managed Care (in Polish PTKOZ) as the organised action of participants in the system to achieve the high cost-effectiveness of services, the quality of medical care and its continuity for the patient. According to PTKOZ coordinated, in Polish KOORDYNOWANA, health care should be:

$\mathrm{KO}$ - comprehensive and integrated;

OR - organizationally controlled;

DY - dynamically responding to the needs of the participants;

$\mathrm{NO}$ - modern and of high quality;

WA - valuable and effective;

$\mathrm{NA}$ - referring to the world-proven solutions [9].

However, in accordance with the definition of the $\mathrm{Na}$ tional Library of Medicine, coordinated care is a set of actions "aimed at achieving a high level of health care while reducing care costs through a variety of mechanisms, including: economic incentives for doctors and patients, motivating them to choose optimal forms of care; mechanisms for assessing the medical necessity to provide particular services; balancing the costs borne by the beneficiary; controlling hospital admissions and the length of stay; establishing incentives for conducting outpatient procedures; selective contracting of health care providers and intensive management of high-cost health care" [5]. This complex set of health care management tools is often called an "art." It is a collection of financial techniques and stimuli for doctors and patients, which through their skillful combination, improves the quality and effectiveness of health care [6]. The notion of coordination in health care can be considered as being a very broad range of institutional solutions $[4,10]$.

\section{The role and aims of coordinated health care}

The philosophy of coordinated health care can be reduced to the optimal allocation of scarce resources, improving efficiency and effectiveness in meeting the real and changing health needs of individuals and entire societies. Coordinated healthcare aims at eliminating all forms of waste, it focuses on cost control (their optimisation), high quality and the availability of health services and it is fully patient oriented. One of the distinguishing features of the concept of coordinated health care is the attempt to provide patients with access to a relatively wide basket of health products and services within the usual system of prepayment.

The philosophy of coordinated health care is frequently put into practice by coordinated care organisations (in Polish OOK), whose aim is to meet the patient's needs most effectively, with reference to the clinical quality and cost, by using their own resources and those of other health care providers. A. Kozierkiewicz lists the following expectations for this form of organisation: (1) patient centred care; (2) outcome oriented care; (3) value-based competition; (4) innovation and responsiveness to patients' preferences; (5) performance-based financing (P4P) [5].

The concept of coordinated care is to contribute to solving at least some of the problems of modern health care systems by leveraging economic incentives to increase the overall efficiency of the system, thereby offering better care at lower cost [3]. Organisations operating according to the principles of coordinated care can control operating costs, by taking over the function of risk management, and therefore the function of the insurer. The characteristic institutions for the concept of coordinated care are entities created, to take over the financial risks associated with medical care and to manage it [3]. As the primary purpose of insurance companies is to share individual risk, the primary goal of coordinated health care is to reduce the average cost of health care. It is, however, considered that the role of the insurer is secondary to the basic task of the managerial role of delivering appropriate-high quality health care that is, at the same time, cost effective. As indicated by the name itself, coordinated care is a form of medical service, which is not limited solely to the particular case, the ethical motives and professional knowledge of doctors, but also to the vitally important elements of coordination, its planning and control $[4,6]$. The role of the supplier, the organiser, the guide, the coordinator, the planner and the supervisor, that is, in the full sense of the word, the manager, comes to the front. The experience of many countries shows that coordinated care can help to optimise costs. The analysis of the implemented coordinated care programmes indicates that reducing the period spent in hospital may be achieved by a greater share of the treatment being provided by outpatient services and community care. The possibility for the care provider to plan the details of the care and the patient's route makes the care, not only more effective and tailor-made for the patient, but also less expensive to implement [11]. It is worth stressing that cost optimisation does not entail reducing the quality of patient care, on the contrary, one of the main assumptions of the philosophy is an increase in the quality of patient care. Thus, the main goal of coordinated care is to simultaneously improve quality and cost efficiency. The attempts to introduce and develop this concept are therefore motivated by the intention of simultaneously increasing quality and reducing costs $[12,13]$. 
Similarly, the primary goals of coordinated care have been defined by the Institute for Healthcare Improvement (IHI) as a triple aim: improving patient satisfaction, improving the health status of the population and reducing the costs of the health care system [12]. The three aims and their sequence reflect the essence of the coordinated health care concept most appropriately. Regardless of what is done in the health system, patients should always stay at the heart of all activities, as health systems are created, maintained and improved for them. The concept of coordinated care is patient-oriented and it is always focused on the patient who is perceived as a whole-holistically. Therefore, the patient should never feel abandoned and must not experience the sense of being at a loss, confused or lonely within the system. On the contrary, the patient should be aware that he has access to comprehensive care and can count on a guide who will lead him through the system appropriately to meet his individual and changing needs. Thus coordinated care is a system of flexible care. This approach to care is designed to enable the patient to move quickly and smoothly between the stages of care - from prevention, diagnosis and treatment to post treatment care. The coordinator is to provide the patient, in any case, with an organisation which ensures that the patient receives all the services needed in a timely manner and with the appropriate quality. The main beneficiary of the implementation and functioning of coordinated care should therefore be the patient, but the patient is not the only beneficiary.

The results of the OECD study on the practice of health care coordination, are worthy of consideration. In 2006 OECD launched a survey in 38 member countries including the EU member states, although 6 are not members of OECD. The aim was to identify the perceived roles of the systems of health care coordination, their performance and outcomes. The study focused on specific care coordination programmes for treating either, defined disease units, or defined groups of patients with specific health needs. The analysed programmes included care management; case management, continuing care, disease management, episodes of care, and pathways [14]. In the study, the objectives of coordinated health care were identified as follows (Figure 1).

According to the survey, the main objective of coordinated health care should be to improve the quality of care through greater convergence of the links between the delivery chain and its compliance with evidence-based medicine (100\% positive indications). The second most frequently stated objective was to increase the cost-effectiveness of care-indicated by $85 \%$ of the respondents although $8 \%$ gave a negative response. The third argument for the introduction of care coordination programmes was to improve access to services, indicated by $77 \%$ of the respondents with, $12 \%$ having the opposite opinion. The responses are in line with the three main objectives of the coordinated care concept cited by the Institute for Healthcare Improvement.

However, when asked about the perceived outcomes of implementing care coordination programmes, in terms of their impact on effectiveness, $54 \%$ of respondents indicated that in most cases the effects of reducing hospitalisation in acute hospitals was positive, although $11 \%$ disagreed. Reducing the overall cost of closed care units by continuing the care in less costly outpatient units received $46 \%$ of positive responses with $12 \%$ responding negatively. A reduction in the number of repetitive hospital admissions was regarded positively by $42 \%$ of respondents and negatively by $8 \%$. At the same time, a significant number of respondents were not able to assess the impact of care coordination programmes on cost-effectiveness, mainly because of the lack of formal evaluation processes and the lack of data for comparative analysis. $89 \%$ of respondents considered that the overall economic impact of such measures was rarely monitored $[14,15]$. This supports the opinions of many experts, who point out that there is no substantial scientific evidence that coordinated care is cheaper, but at the same time it is fairly commonly said that it certainly provides better

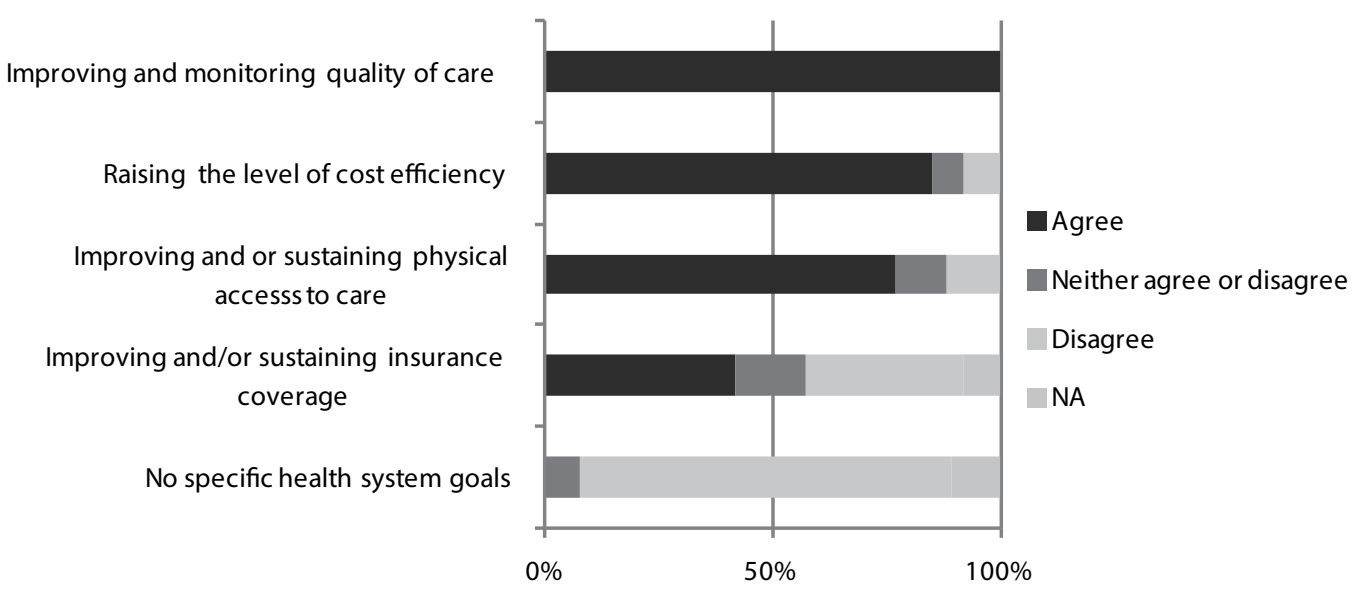

Figure 1. The purpose of health care coordination.

Source: Hofmarcher M., Oxley H., Rusticelli E., Improved health system performance through better care coordination, "OECD Health Working Papers" 2007; 30: 1-86 [14]. 
care for the patient. The study also identified the impact of solutions coordinating the quality of care and collaboration with patients. When asked if coordination in health care contributes to a reduction of medical errors $50 \%$ responded positively with $11 \%$ having a negative opinion; guaranteeing more rapid access to services received $50 \%$ positive answers and $8 \%$ negative; increased patient satisfaction $46 \%$ positive $12 \%$ negative; and that it influences beneficially on the so-called 'self-healing', received a $46 \%$ positive response and $12 \%$ negative. However, respondents did not accept that the flow of information between providers was more complete and faster as only $31 \%$ gave positive answers with $23 \%$ giving a negative response.

It appears that the general opinion, expressed in public discussions, about the low level of coordination between the various levels of health care, has strong empirical support. Numerous studies at various centres confirm this belief and provide the justification for implementing elements embedded in the broad concept of coordinated health care and the supportive concept of integration into the health care systems (Table I).

\section{Principles and characteristics of coordinated health care}

Entities applying the concept of coordinated care, regardless of the organisational dominant, apply two fundamental principles: the principle of suitability and substitution - the so-called " $2 S$ " principle:

- The principle of suitability means providing patients with appropriate health care tailored to their individual and actual health needs.

- The principle of substitution means the use of available cheaper and equally effective treatments $[4,6]$.

Any medical organisation, including one which does not exemplify coordinated health care, will benefit from these two principles. In health care systems where the two principles are not applied, there is greater concerns about "how to get a patient to a vacant hospital bed" a philosophy of resource financing - than the focus on "how to best solve the patient's health problems" - a philosophy of financing needs $[4,16]$.

The above principles can be implemented by creating a system of incentives, sometimes called "active buying mechanisms" [17], which are divided into three groups: (1) financial incentives to spread the financial risk between the buyer and the health care provider; (2) patient-oriented incentives, which limit their autonomy in the choice of treatment; (3) incentives for medical services providers manifested by the management of clinical decisions [4].

Quite commonly, the main feature of coordinated care, which is often referred to as the primary distinguishing and fundamental requirement for coordinated health care, is the presence of a leader, or coordinator, in the system [4]. The role of the coordinator may be entrusted to:

- a primary care doctor acting independently, as in the United Kingdom in the early 1990s;

- a multidisciplinary outpatient health care or a network of centres, including primary care and others, the IPA - Independent Practice Association, model from the USA, Switzerland and pilot schemes in Germany and Hungary;

- a hospital and an outpatient care network (primary and specialist); (IDS - Integrated Delivery System; staff model HMO in the USA; ACO - Accountable Care Organization in Barack Obama's plan; the Alzira model in Spain);

- the establishment of an administrative and organisational character (most of the MCOs - Managed Care Organizations in the USA; PCT - Primary Care Trust in the United Kingdom, pilot projects in the Czech Republic) [5].

The most common and widespread solution in this matter is the assignment of a coordinator role to a GP, the British model, or an insurance and medical institution, the American model. It is precisely the appointment of a coordinator/manager that should be considered as the essential difference between traditional medical practices and coordinated care. The appearance of a coordinator in the system makes it possible that a patient's problem becomes the coordinator's problem [11]. The characteristic of coordinated care is the transfer of organisational and financial roles to a specialised managerial structure [12]. It is the budget managers that take on the financial and organisational responsibility for ensuring access to a relatively wide range of health services to specific patients [7]. The coordinator must inform to the patient of the subsequent places where he or she is to be treated. The coordinator's role is to deliver full documentation to the next care unit and should be given feedback on the care provided at subsequent care units. The coordinator should provide comprehensive care, or focus on its coordination if he, or she, cannot provide it. With the proper organisation of such care for the patient, it should not be detrimental. Properly coordinated care will always be comprehensive, regardless of whether the provider will deliver care for the patient without the involvement of other providers or with their involvement [11]. In addition, the philosophy of coordinated care assumes that the manager examines the treatment process and controls the flow of funds, in some cases facilitating payments and retaining them in others. Coordinated care providers are, therefore, taking over financial responsibility for medical care and consequently they have good reason to ensure the effectiveness of services. In order to stay on the market, they must be competitive both in terms of quality and cost. They must maintain the difficult balance between expenditure control, administrative action and medical uncertainty [3]. Care coordination imposes new responsibilities on the caregiver. The role of the provider (coordinator) does not end with providing a single service. There is a need to organise care at other stages of treatment, to implement mechanisms for exchange of information and medical records between institutions [11].

The characteristic of the concept is also the financing of the broad range of pre-payment health care, using capitation techniques $[3,4,6,10,18,19]$. Another distinguishing feature of this approach to care is the holistic view of the patient and his or her problems. The 


\begin{tabular}{|c|c|}
\hline $\begin{array}{l}\text { Gaps in the coordination and } \\
\text { integration of care }\end{array}$ & The consequences of lack of coordination and integration in health care-empirical findings \\
\hline Between GPs and specialists & $\begin{array}{l}\text { - } 45 \% \text { of specialists do not provide feedback to GPs } \\
\text { - } 28 \% \text { of GPs and } 43 \% \text { of specialists considered that the level of information flow between them was } \\
\text { unsatisfactory } \\
\text { - } 25 \% \text { of GPs did not receive the results of specialist consultations even } 4 \text { weeks after the visit }\end{array}$ \\
\hline $\begin{array}{l}\text { Between GPs and Emergency } \\
\text { services }\end{array}$ & $\begin{array}{l}\text { - } 33 \% \text { of emergency ambulance visits did not have complete medical records } \\
\text { - } \quad \text { Every third family doctor does not know about the emergency intervention given to their patients }\end{array}$ \\
\hline $\begin{array}{l}\text { Between doctors and diagnostic } \\
\text { centres }\end{array}$ & $\begin{array}{l}\text { - In } 17 \% \text { of cases, the GP did not have diagnostic results at the planned, subsequent visit of the } \\
\text { patient } \\
\text { - In } 22 \% \text { of chronically ill patients treated by one doctor and in } \mathbf{4 3 \%} \text { of patients treated by four } \\
\text { or more doctors at the same time, repetition of diagnostic tests occurred }\end{array}$ \\
\hline Between hospital doctors and GPs & $\begin{array}{l}\text { - } 1 / 3 \text { of hospitalised adult patients with chronic disease did not receive any guidelines for further } \\
\text { therapy after hospital discharge } \\
\text { - } 60 \% \text { of GPs did not receive any information about further pharmacotherapy and recommended } \\
\text { treatment for their patients after hospitalisation } \\
\text { - } 3 \% \text { of GPs had the opportunity to consult a hospital doctor on the planning of their patients' } \\
\text { discharge } \\
\text { - In } 66 \% \text { of cases, GPs undertook further treatment of their patients after hospitalisation without any } \\
\text { discharge information }\end{array}$ \\
\hline $\begin{array}{l}\text { Between outpatient doctors and } \\
\text { patients and their families }\end{array}$ & $\begin{array}{l}\text { - } 33 \% \text { of doctors do not notify patients of confirmation of malign or unwelcome results of the recom- } \\
\text { mended diagnostic or medical tests } \\
\text { - } 18 \% \text { of patients treated by a few doctors at the same time received contradictory medical recom- } \\
\text { mendations } \\
\text { - } 24 \% \text { did not receive a response to an important question about their own treatment, and } 41 \% \text { did } \\
\text { not receive information on the side effects of the recommended pharmacotherapy } \\
\text { - } \mathbf{5 0 \%} \text { of patients leaving the doctor's surgery did not understand the message } \\
47 \% \text { of patients who were asked to repeat a doctor's recommendations could not do it correctly. } \\
\text { This indicating a lack of clarity on the part of the doctor } \\
\text { - } 9 \% \text { of patients were allowed to participate in medical decisions }\end{array}$ \\
\hline $\begin{array}{l}\text { Between hospital doctors and } \\
\text { patients and their families }\end{array}$ & $\begin{array}{l}\text { - } 48 \% \text { of adult hospitalised patients were not informed about the side effects of the provided pharma- } \\
\text { cotherapy, and } 67 \% \text { of those who were prescribed new medications did not receive information on } \\
\text { whether to continue to use pre-hospitalisation medication }\end{array}$ \\
\hline
\end{tabular}

Table I. Gaps in the coordination/integration of health care and their consequences.

Source: Rudawska I., Zintegrowana opieka zdrowotna. Podejście relacyjne do obstugi pacjenta jako klienta, Wolters Kluwer, Warszawa 2014 [7]; WHO - Światowa Organizacja Zdrowia, Innovative care for chronic conditions: Building blocks for actions, Genewa 2002 [36]; Bodenheimer T., Coordinating care - a perilous journey through the health care system, "The New England Journal of Medicine" 2008; 10 (358): 1064-1071 [37].

providers of such care do not divide the services into outpatient, hospital, specialist, etc. Instead, they focus on solving a particular health problem and on the care of a patient suffering from a particular illness, without subdividing treatment into particular services. The provider focuses on solving a specific health problem while the payer finances the effect of treatment rather than its individual steps [11]. The concept of coordinated health care is not limited to one method of financing the providers, e.g. capitation or P4P. Typically, mixed systems are used which combine the advantages of particular funding methods for the providers and at the same time limit their disadvantages, as none of the existing methods of financing providers is devoid of weaknesses.

The EBM (Evidence Based Medicine) institutions are another essential element of coordinated care, similar to the principle of co-financing services by patients (regulation of demand by patient co-financing) [4]. The hallmark of the concept of coordinated care, which is usually indicated as the primary argument by opponents, is that there are some restrictions on the autonomy of both patients and providers which impose additional responsibilities for the parties. The restrictions apply mainly to the choice and imposition of certain patterns of conduct. On the demand side, the contract between the coordinated care plan and its members imposes various restrictions and obligations on patients. The participants in the plan may benefit only from selected hospitals, doctors, designated pharmacies and therapeutic centres, may have the requirement to complete forms, or make telephone calls to obtain agreement for using the services and cooperate with the system in many other ways to obtain access to care. As a result, patients undertake some part of the managerial work [3]. The idea of coordinated health care implies the implementation of all these activities to make the patient more interested and take responsibility for his or her health (self-coordination). On the supply side, coordinated care insurance planners must sign contracts with a sufficient number of doctors, hospitals and other types of medical centres, to create a network of providers, where patients can receive all the necessary services [3]. 
In coordinated care, the patient and his, or her, changing health needs are most important, and this must be emphasised. Coordinated care is not only to improve the clinical effectiveness and economic efficiency, but also, and should above all, to increase patient satisfaction. One of the most important characteristics of coordinated care is the promotion of patient orientation. This concept emphasises a holistic approach that embraces the medical, social and psychological needs of the individual in a linked and comprehensive manner. This approach distinguishes the concept from traditional health care organisations, in which caregivers focus on particular care episodes, but not on the whole process.

The above features clearly define a new model (paradigm) of health care: patient-focused, continuity-oriented, results-oriented, and provided by prepared medical entities. The specificity of this model is the active adaptation of the services provision to variable patients' preferences, the promotion of organisational and technological innovation and the transfer of competencies to the lowest effective level, i.e.to primary care and the patients themselves [13, 20] (Table II).

It should be noted that the above aspects are not only characteristic of the philosophy of coordinated health care, but their combined, coherent and well-thoughtthrough appearance is commonly associated with the described and analysed concept. It is the overall management which takes these elements into account that is the primary determinant of coordinated care.

\section{The concept of integration in health care}

The Latin word integratio means "renewal", and the derivative term integer means "untouched", "whole", "total/complete". The Polish Dictionary of Foreign Words and Expressions defines the term "integration" as the process of creating a whole from parts, as well as combining and harmonizing the components of the community [21]. Health integration can be defined as the intentional process of combining, or merging, many and different elements of a health system, the functions, organisations, management activities and medical treatment. In practice, integration in the field of health means merging the activities undertaken by several entities into one organism, or merging individual activities into a collective action. This merging process may involve many aspects such as: combining primary and specialised care into one organisational formula; integrating health services within the scope of one insurer (e.g. HMO); combining treatment methods according to a standard path of medical procedures for a patient in general, or one with defined diseases (e.g. oncology packages); integrating health services into one location (e.g. a clinic, school, or workplace); integrating health services into one defined group of patients (e.g. children, the elderly); or integrating primary health care with social care at a central or local level.

By the 1990s, the integration of health care was interpreted as an antonym of care fragmentation, a synonym of comprehensive care, communication and managerial continuity, and even as a team of medical professionals [22]. However, today the integration of health care is often considered in two dimensions:

1) as an organisational structure subordinated to the economic demands, consisting of the formation of capital groups (organisationally integrated entities) which combine various aspects of the health sector (from hospitals to outpatient care to pharmacies). This interpretation of integration links it strongly with the notion of mergers and acquisitions [23];

2) as a means of providing health care by coordinating various activities, of which the final beneficiary is the patient. A measure of achievement from this perspective is the improvement of the outcome of treatment with simultaneous attention to the costeffectiveness [24].

Typically, the first, or structural approach, is identified with integration, while the second, a process approach, is identified with coordination. For the process approach to integration it is characteristic that the cooperating entities remain independent organisations that are united by the terms of the contract and not by the right of ownership. However, the first perspective of defining the integration of health care requires the creation of a unified legal and management structure which combines several organisations into one. The right of ownership becomes the mechanism of coordination, and the previously independent entities lose their autonomy to the new structure [7]. Coordinated care can, therefore, be perceived as a process approach to integrated care. In a paper analysing the approaches to the integration of health care in six EU countries I.N. Fabbricotti wrote, "Integrated health care is a coherent and coordinated set of services that are planned, managed and provided to

Features of coordinated care

Patient orientation (holistic approach), coordinator (leader), comprehensiveness, continuity, suitability, substitution, quality, availability, integration, wide baskets of goods and services, prepayment, capitation, co-payment, deduction pool, paying for results, a GP, EBM, networking, concentration on a treatment process (not on individual services), higher risk group identification, lack of fragmentation, information and documentation exchange, information and information technology systems, performance orientation, flexibility to meet changing needs, patient involvement, organisational and technological innovation, decentralisation, small limitation of patients' and providers' autonomy, new responsibilities of providers, creation of incentives for patients and providers, focus on disease prevention and health promotion.

Table II. Features of coordinated care.

Source: Own study, 2017. 
individual beneficiaries of services, through a range of organizations and a range of collaborating medical professionals and non-formal care providers (carers)" [25]. D. Kodner and C. Spreeuwenberg define integration as a set of methods and models for financing, administering and organising service processes aimed at linking, stimulating collaboration and equalising disproportions within the levels of treatment in the strict sense and the levels of care between them [26]. Other suggestions emphasise the responsibility for the taken actions, interpreting integration as "a network of entities that provide or arrange a coordinated service continuum for a defined population and which is able to accept clinical and financial responsibility for the results and health status of the community it serves" [15, 27].

In the context of the various interpretations of the term - integration - and generally identifying it with the term coordination, the definition proposed by WHO in 2001 is accepted in this study. The WHO has stated that integrated care is a concept that combines resources at the entrance, the process service provision, management and organisation of health services in relation to diagnosis, therapy, rehabilitation and health promotion [28].

\section{Dimensions of integrated care in health care}

Integration in health care can be vertical or horizontal. In the first case, vertical integration, there is a vertically integrated supply chain that, through a formal contract or institutional right of ownership, is focused on building a comprehensive and cost-effective medical service for the relevant population $[29,30]$. In this case, the coordination mechanism role is played by formal contracts and rights of ownership. Recently, there has been an increased interest in vertically integrated healthcare. However, in the case of horizontal integration, institutions that provide similar service are linked. For instance, two hospitals, or services that are very different but not creating logically distinguished stages of the process are merged - a hospital with the distribution of drugs [31].

Integration can also have different "depths" and "widths". The "depth" is defined by the type of providers participating and the number of integrated sectors. It is ideal when integration covers the whole range of services from the first contact with outpatient treatment, through residential care, to home care and rehabilitation. In contrast, the "breadth" of integration is determined by the agreed spectrum of diseases. It may involve a single diagnosis, i.e. integrated care is dependent on the diagnosis, to the total care of the population of a particular region irrespective of recommendations i.e. integrated care focused on the population) [6].

In the context of the two dimensions of health care integration, two organisational and financial models of integrated care should be recognised: the disease management pathways (DMP) model and the population model. The first is based on the co-ordination of the process of delivering services to the group of patients suffering from certain, mostly chronic, high-cost diseases in the course of the entire therapeutic process $[12,32]$.
The genesis of the population model, however, should be detected in the growing conviction, supported by reliable scientific evidence, that a person's socio-economic status and lifestyle has a very important influence on health. The population model, in contrast to the DMP model, is geared towards the whole population and envisages actions to influence the social, economic and environmental determinants of health. It takes a wider approach than the DMP model, including the promotion of healthy lifestyles, prevention and the desire to reduce socioeconomic disparities. It requires the integration of health care and widely understood social care. The population model is now being perceived as superior to the traditional DMP model, which is criticised for focusing on medical services per se instead of improving the health of the population $[12,33]$. In the literature there are many forms of integration in health care, including structural, referring to the management structure; clinical, referring to the continuity of care and information, referring to the clinical and administrative data systems [27]. In addition, health integration can be defined at three levels - macro, meso and micro. The macro level is concerned with health, social and cross-sectoral policies, the meso level with cooperation between different treatment entities and micro level with the integration of the provision of medical services at the patient level [7]. S. Kagan lists four further dimensions of integration depending on what is at its heart [34], (1) health policy-oriented integration; (2) organization-oriented, or service provider, integration; (3) treatment programme-oriented integration; (4) single patient-oriented integration. D.L. Kodner and C. Spreeuwenberg indicate five areas of health care integration, namely, financial, administrative, organisational, process and clinical.

\section{Coordination versus integration in health care}

Coordinated care is often identified with integrated care. Both concepts are commonly referred to in literature, unconsciously or intentionally, as convertible terms. Both are perceived in health care as systemic solutions, postulated paradigms for organising and delivering health care, recognising the primacy of a holistic view of the patient. However, the two terms must comprise other aspects. Primarily, coordination means, the harmonised interaction of different entities and issues, often autonomous and from outside the health sector, while integration in health care is mainly concerned with the intentional process of combining many and various elements into one system.

Coordination is often considered as an intermediate solution prior to full integration [7, 34] (Figure 2).

On the one side of the above continuum, there is informal cooperation, and on the other - the integration of the service providers. The origins of integration and coordination in health care should therefore be found in informal cooperation between staff and in social relationships. Formalising this co-operation through a contract, by establishing the time and subject matter, leads to coordination of the service at a later stage. The most advanced 


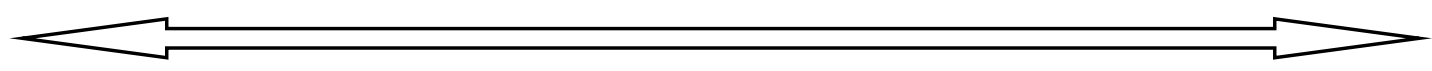

\begin{tabular}{|c|c|c|c|}
\hline $\begin{array}{l}\text { Informal } \\
\text { Cooperation }\end{array}$ & $\begin{array}{l}\text { Formal } \\
\text { Cooperation }\end{array}$ & Coordination & $\begin{array}{l}\text { Integration of } \\
\text { Service providers }\end{array}$ \\
\hline
\end{tabular}

Figure 2. Continuum of inter-organizational arrangements in the health care sector.

Source: Rudawska I., Zintegrowana opieka zdrowotna. Podejście relacyjne do obstugi pacjenta jako klienta, Wolters Kluwer, Warszawa 2014 [7]; Selden S.C., Sowa J.E., Sandfort J., The Impact of Nonprofit Collaboration in Early Child Care and Education on Management and Program Outcomes, "Public Administration Review" 2006: 3 (66): 412-425 [34].

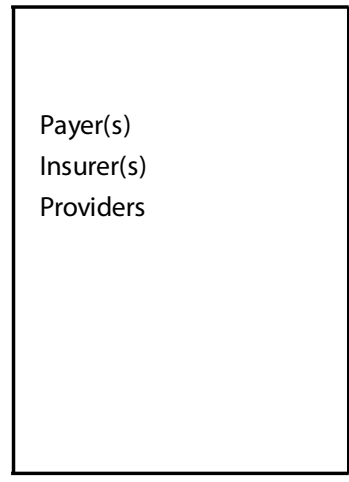

(A)

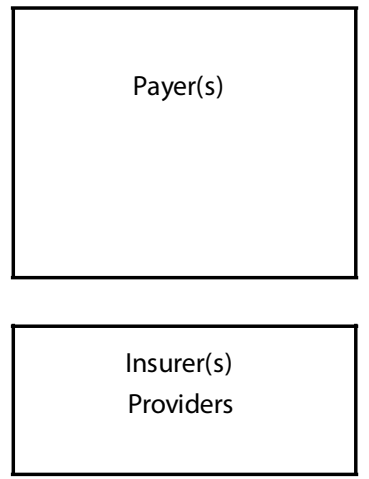

(B)

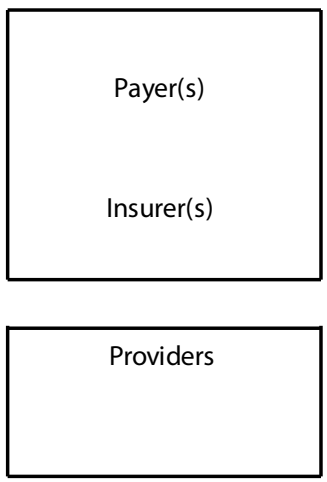

(C)

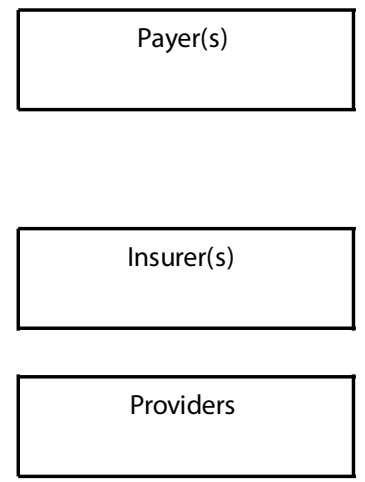

(D)

Figure 3. Types of integration of health care system components.

Source: Getzen E.T., Ekonomika zdrowia. Teoria i praktyka, Wydawnictwo Naukowe PWN, Warszawa 2000, 2004 [3]; Kornai J., Eggleston K., Welfare, Choice and Solidarity in Transition. Reforming the Health Sector in Eastern Europe, Cambridge University Press, Cambridge 2011 [38].

form of inter-organisational activity is an integration of service providers that launches multiple mechanisms simultaneously, such as joint planning, joint budgeting and joint treatment programmes for patients [7].

Coordination is the organisation of activities performed jointly by many people or the harmonious functioning of something. Whereas, integration is the process of creating a single entity from several parts, the merging individual parts into one. Both terms are characteristic of the concept of coordinated health care. In the paradigm of coordinated health care- integration is its characteristic feature, but it does not prejudge the existence or non-existence of the concept of coordinated health care. Any kind and range of integration may occur within the framework of coordination. Depending on the structure and degree of integration, the coordinated health care organisations are able to:

- manage only the process of acquiring medical care for an eligible population by concluding contracts with the providers of medical services, or

- organise medical care and at the same time are the providers of services $[4,6]$.
In the philosophy of coordinated health care, integration is most often identified with integrating the functions of the purchasers and providers of health services. This is commonly considered one of the characteristic ("classical") features of coordinated health care. The integration process is characteristic of the concept of coordinated health care, however, this is not a prerequisite for this concept to exist. Nevertheless, the type and scale of integration can vary widely. From the point of view of the operation of the whole health care system, an appropriate form of organisational dependence to determine the relationships between the components of the system is essential. These relationships can be described: by the degree of integration between these components: the payer, the insurer and the medical services provider (Figure 3) [4].

In each of the presented variants, the same components exist, except that they have different configurations [3]. Thus, depending on the choice of the organisational form, the same components create different variants. There are two, so-called pure, forms of organisation: integration (type A) and separation (type D) and two in-between forms (B and C) (Figure 3). Therefore, it 
is clear that within the concept of coordinated health care, there may be different solutions to the degree and scope of integration in undertaking such functions as payment, insurance or health care. This flexibility in integrating these functions contributes to the fact that, in practice, especially in the American system, there is a great diversity of organisational forms within the context of coordinated healthcare, despite the same principles and techniques being applied. This variety has made the US health system often being described and reported as a pluralistic system and even a so called non-system.

\section{Weaknesses and threats of the concept of coordinated health care}

The philosophy offers many opportunities to solve numerous problems and challenges facing the modern systems of healthcare. However, the concept carries several threats, which should not be underestimated.

The concept assumes minor limitations of the patients' access to higher levels of care. These limitations have been raised by many critics of the concept as proof of it not taking into account the individual approach to treatment and the sometimes lower quality of health care provided by coordinated health care organisations. The alleged accusation of lower quality care is not, however, justified in the light of the results of evaluation studies, or by how much the concept has influenced the development of health care quality assessment measures as an important element for the evaluation of health care systems [6].

Most of the concerns about the philosophy of coordinated health care are related to the primary form of care funding, meaning capitation, e.g. the risk of patient selection or the risk of reducing the time spent on care. Many allegations are directed at another method which is increasingly used, that is pay for performance ( $\mathrm{P} 4 \mathrm{P})$. This method is claimed to be complicated and that its implementation and operation requires substantial expenditure, stressing the need to create registers, indicators and the acquisition of costly IT systems, etc. However, it is important to recognise that any form of provider funding may, to a lesser or greater extent, threaten the availability or quality of the health care given to the patient. By adopting the right techniques, the potential risks can be significantly reduced, or even eliminated.

An important weakness of the concept of coordinated health care is the limitation of the providers' autonomy. Through the use of only certain entities (the "guards" of the system, or the possibility of directing referrals only to a specific group of specialists, etc.), supervision of the medical decision-making process has developed, and thereby the management of care by doctors has been replaced by "bureaucratic" management. It should be remembered, however, since its origin the concept has presupposed the existence of certain limitations on the autonomy of the patient and doctors, treating them as a conscious management tool, rather than it being a consequence of the side effects of coordinated healthcare. It is much easier to coordinate care when the links between the various care providers are institutionalised through a system of contracts or integration when multidisciplinary teams are created [4].

Greater bureaucracy and increased costs are also mentioned, especially in the early stages of the implementation and development of the concept of coordinated health care, caused by the need for expenditure on information and information technology systems. Nevertheless, even if in the short term the costs outweigh the potential benefits, the potential benefits in the long run, will certainly be higher than the costs incurred during the early stages of implementation, which should be considered as an investment. In fact, properly implemented and widely used information and information technology systems should contribute to reducing bureaucracy in health care.

Another weakness of the concept of coordinated health care is the temptation to select risks. The main consequence of this is the increasing inequality in access to health care. However, the selection of risks, that is "a skimming strategy" by health care providers, can be eliminated by appropriate protective measures such as deciding to differentiate capitation rates for people who potentially could pose a higher risk of ill-health. The capitation rate can be calculated on the basis of the following criteria: sex, age, identified disease unit, risk group, place of residence. There are compensatory mechanisms that improve efficiency and justice with regard to the population covered [35].

In addition, if the regulations do not adequately specify the allocation of costs, competencies and responsibilities for different levels of medical care within the concept of coordinated care, conflicts, grievances and accusations may arise that will contribute to the strengthening of divisions and thus fragmentation in the system of health care [6]. These risks, however, will not arise if the issues that may potentially cause conflicts are clearly and appropriately regulated.

It is also worth recognising that when criticism of coordinated health care occurs, attention should be paid to its source. In the case of American coordinated health care, there are at least three very strong interest groups that depend on the negative image of coordinated care. These include the traditional insurance companies, the groups of independent practice specialist doctors and the of "acute" hospitals sector. The philosophy of coordinated health care has significantly impaired the financial interests of these three groups. The list of interest groups can certainly include the media, for which negative information is the "best" information [4].

The second part of this text will be published in the next volume of the journal of Public Health and Management. In the next part of this article will be presented experiences of coordinated and integrated health care in Poland.

\section{Notes}

1 There is a significant difference between coordinated care and comprehensive care. When a provider is not able to supply a patient with full (comprehensive) care because of a limited range of services (or a wide spectrum of patient's needs), they 
should take action to coordinate the care so that the patient receives comprehensive care (with the participation of other providers). Summing up, from the patient's level, the care should always be comprehensive. However, the provider supplying coordinated care does not always have to do it in a comprehensive manner.

${ }^{2}$ In the health care it frequently happens that two or more entities share their recourse base. The activity to create coalition in order to strengthen the market position of partners is rare. In such a case the use of mutual recourses in the network has cost consequences leading to their rationalisation. Because of the change in the demographic-epidemiological profile of modern societies, the networks of cooperating entities seem to be suitable for facing such a demand model. There is no entity in health care, which would be large enough, in the meaning of competences, to satisfy all the needs of patients in a given time. This means that the main interest is access to the resources of knowledge, experience and technology and not to the possession of those resources [7].

\section{References}

1. Michalak J., Rybarczyk-Szwajkowska A., Dzieje koordynowanej opieki zdrowotnej $w$ regionie tódzkim i mieście Łodzi - studium przypadku, "Journal of Health Policy, Insurance and Management - Polityka Zdrowotna" 2015; XVI: 127-151.

2. WHO - Światowa Organizacja Zdrowia, Integrated Care Models: An Overview, Copenhagen 2016.

3. Getzen E.T., Ekonomika zdrowia. Teoria i praktyka, Wydawnictwo Naukowe PWN, Warszawa 2000, 2004.

4. Kowalska K., Koordynowana opieka zdrowotna. Doświadczenia polskie i międzynarodowe, Wydawnictwo Uniwersytetu Warszawskiego, Warszawa 2009.

5. Kozierkiewicz A., Konsolidacja i integracja opieki zdrowotnej, Unia Europejska, Warszawa 2011.

6. Kowalska K., Kalbarczyk W.P., Koordynowana opieka zdrowotna. Doświadczenia międzynarodowe, propozycje dla Polski, Sprawne Państwo Program EY, Warszawa 2013.

7. Rudawska I., Zintegrowana opieka zdrowotna. Podejście relacyjne do obstugi pacjenta jako klienta, Wolters Kluwer, Warszawa 2014.

8. Czakon W., Sieci w zarzadzaniu strategicznym, Oficyna a Wolters Kluwer business, Katowice 2012.

9. PTKOZ - Polskie Towarzystwo Koordynowanej Opieki Zdrowotnej 2017, Definicja KOZ, http://ptkoz.org/ (accessed: 31.03.2017).

10. Glied S., Managed Care, in: Culyer A.J.; Newhouse, J.P. (eds.), Handbook of Health Economics, vol. 1A, vol. 1B, Elsevier, Amsterdam 2000.

11. Zawalski W., Opieka koordynowana, czyli produkt szyty na miare, "Menedżer Zdrowia" 2016; 8: 46-50.

12. Hermanowski T., Rutkowski J., Zintegrowana opieka zdrowotna. Zarys problematyki, "Zeszyty Naukowe Politechniki Śląskiej. Organizacja i Zarządzanie” 2015; 83: 225-233.

13. McDonald K.M., Sundaram V., Bravata D.M. et al., Closing the Quality Gap: A Critical Analysis of Quality Improvement Strategies. Vol. 7: Care Coordination, "Technical Reviews" 2007; 9: 1-210.

14. Hofmarcher M., Oxley H., Rusticelli E., Improved health system performance through better care coordination, "OECD Health Working Papers" 2007; 30: 1-86.
15. Rudawska I., Zintegrowana opieka zdrowotna - w poszukiwaniu poprawy efektywności, "Problemy Zarządzania" 2011; 3 (33): 140-152.

16. Tymowska K., Kontrakt jako instrument tworzenia relacji między nabywca a dostawca świadczeń zdrowotnych, “Antidotum - Zarządzanie w Opiece Zdrowotnej” 1993; 2: 84-90.

17. Costs K.N., Productivity and financial outcomes of managed care, in: Saltman R.B., Otter C. Von, Implementing Planned Markets in Health Care, Open University Press, Buckingham-Philadelphia 1995.

18. Mays N., Wyke S., Malbon G., Goodwin N., The Purchasing of Health Care by Primary Care Organizations. An Evaluation and Guide to Future Policy, Open University Press, Buckingham 2001.

19. Kongstvedt P.R., Essentials of Managed Health Care, Jones \& Bartlett Publishers Inc., USA, Burlington, Massachusetts 2003.

20. Zapaśnik A., Skłucki J., Tumasz J., Szynkiewicz P., Jędrzejczyk T., Popowski P., Koncepcja koordynowanej ambulatoryjnej opieki zdrowotnej, Polskie Towarzystwo Programów Zdrowotnych, Gdańsk 2016.

21. Kopaliński W., Stownik wyrazów obcych i zwrotów obcojęzycznych, Wydawnictwo Wiedza Powszechna, Warszawa 1989.

22. Uijen A.A., Schers H.J., Schellevis F.G., Van den Bosch W.J., How unique is continuity of care? A review of continuity and related concepts, "Family Practice" 2012; 29 (3): 264-271.

23. Devers K.J., Shortell S.M., Gillies R.R., Anderson D.A., Mitchell J.B., Erickson K.L., Implementing organized delivery systems: an integration scorecard, "Health Care Manage Review" 1994; 3: 7-20.

24. Stranberg-Larsen, M., Krasnik A., Measurement of integrated healthcare delivery: A systematic review of methods and future, "International Journal of Integrated Care" 2009; 9: 1-10.

25. Van Raak A., Integrated Care in Europe: Description and Comparison of Integrated Care in Six EU Countries, Elsevier Gezondheidszorg, Netherlands, Amsterdam 2003.

26. Kodner D., Spreeuwenberg C., Integrated care: meaning, logic, applications, and implications - a discussion paper, "International Journal of Integrated Care" 2002; 2 (4), https://www.ncbi.nlm.nih.gov/pmc/articles/PMC1480401/ (accessed: 31.03.2017).

27. Wan T.T., Lin B.Y., Ma A., Integration mechanisms and hospital efficiency in integrated health care delivery systems, "Journal of Medical Systems" 2002; 26 (2): 127-143.

28. Gröne O., Garcia M., Integrated care, A position paper of the WHO European office for integrated health care services, "International Journal of Integrated Care" 2011; https://www.ncbi.nlm.nih.gov/pubmed/16896400 (accessed: 31.03.2017).

29. Lega F., Organisational Design for Health Integrated Delivery Systems: Theory and Practise, "Health Policy" 2007; 81 (2-3): 259-260.

30. Saltman R., Busse R., Figueras J., Decentralization in Health Care: Strategies and Outcomes, McGraw-Hill Education, London 2006. 
31. Włodarczyk C., Poździoch S., Systemy zdrowotne, Wydawnictwo Uniwersytetu Jagiellońskiego, Kraków 2011.

32. Leichsenring K., Developing integrated health and social care services for older persons in Europe, "International Journal of Integrated Care" 2004; 4, https://www. ncbi.nlm.nih.gov/pmc/articles/PMC1393267/ (accessed: 31.03.2017).

33. Alderwick H., Ham Ch., Buck D., Population Health Systems. Going beyond Integrated Care, The King's Fund, London 2015.

34. Selden S.C., Sowa J.E., Sandfort J., The Impact of Nonprofit Collaboration in Early Child Care and Education on Management and Program Outcomes, "Public Administration Review" 2006: 3 (66): 412-425.
35. Ellis R., Van de Ven W.P.M.M., Risk Adjustment in Competitive Health Plan Markets, w: Culyer A.J., Newhouse J.P., Handbook of Health Economics, Elsevier, Amsterdam 2000.

36. WHO - Światowa Organizacja Zdrowia, Innovative Care for Chronic Conditions: Building Blocks for Actions, Genewa 2002.

37. Bodenheimer T., Coordinating care - a perilous journey through the health care system, "The New England Journal of Medicine" 2008; 10 (358): 1064-1071.

38. Kornai J., Eggleston K., Welfare, Choice and Solidarity in Transition. Reforming the Health Sector in Eastern Europe, Cambridge University Press, Cambridge 2011. 